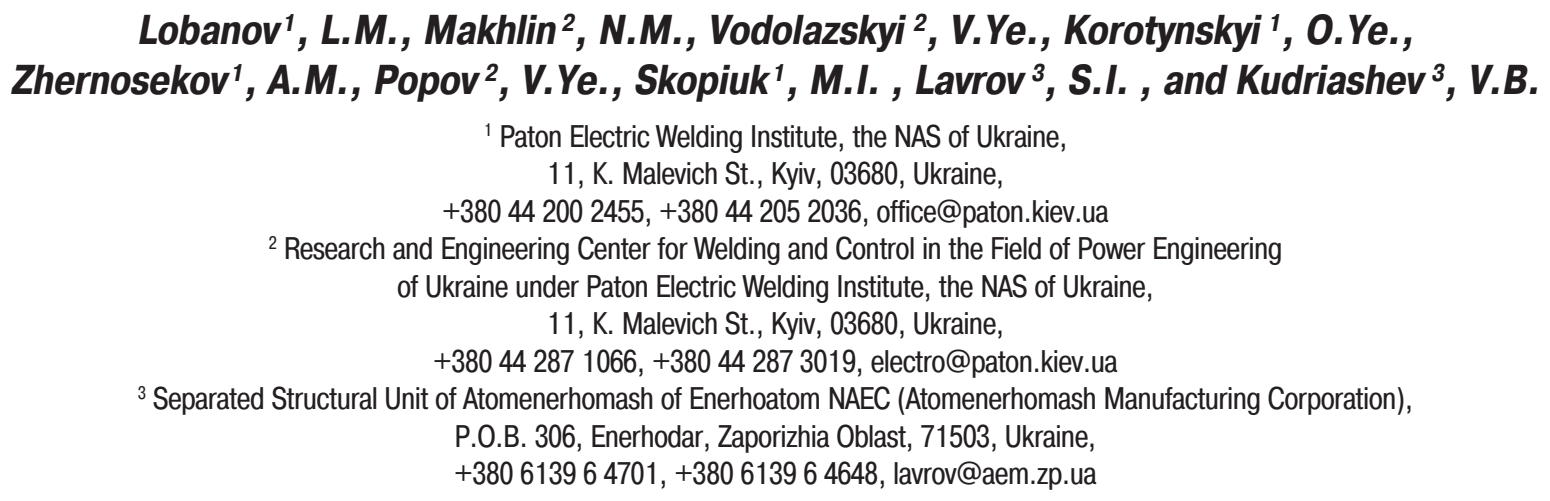

\title{
STATE-OF-THE-ART UKRAINIAN EQUIPMENT FOR MACHINE WELDING OF HIGH-PRESSURE PIPELINES OF THE SECOND LOOP OF NPP UNITS OF UKRAINE
}

Introduction. High-pressure heaters (HPH) are principal components of the second loop of nuclear reactors with pressured water. HPH coils are used to heat water up to required temperature with its further supply to heat exchanger, steam generator (SG). Steam generated by SG is fed to turbines and triggers power generators of NPP unit.

Problem Statement. The main factor that significantly constraints the performance of weld joints of HPH coil tubeworks while manufacturing and repairing and causes their defects is manual TIG welding method (hereinafter referred to as the TIG method) that has been used in the domestic practice so far.

Purpose. To study ways of raising efficiency and performance of weld joints of HPH coil tubeworks and improving their stability and quality, as well as to develop domestic equipment for implementation of elaborated techniques.

Materials and Methods. Steel 20 simulators of HPH tubeworkshave been used for the purpose of the study. The used methods are as follows: mathematical and computer simulation full-scale modelling, trial welding, nondestructive and destructive control techniques, and CAD.

Results. The use of various arc welding techniques for welding HPH coil tubeworkshas been studied, the most optimal method of them, the most effective parameters of welding conditions, and requirements for domestic welding equipment have been identified, technical specifications for the equipment and its main components and respective research and predesign works have been developed, innovative technical proposals concerning its composition, configuration, structure, and other technical solutions have been elaborated.

Conclusions. MIG + MAG welding method with the use of fused electrode (solid-section electrode wire) in protective gases mix has been established to be the most effective and cost-efficient in terms of compliance with the requirements of applicable norms and standards and approved technical specifications with respect to quality and performance of weld joints of HPH coil tubeworks made of steel 20. Manufacturing processes for the design solutions on the major functional nodes and mechanisms of the equipment for implementing the mentioned method have been developed and approved.

Keywords: HPH, HPH coils, machine welding, and welding manipulator.

(c) LOBANOV, L.M., MAKHLIN, N.M., VODOLAZSKYI, V.Ye., KOROTYNSKYI, O.Ye.,

ZHERNOSEKOV, A.M., POPOV, V.Ye., SKOPIUK, M.I., LAVROV, S.I., and KUDRIASHEV, V.B., 2018 
The typical features of HPH coils are associated with weld joints of tubeworks of the coils and their tailpipes and with parameters of medium (feed water) supplied at a nominal pressure $12.0 \mathrm{MPa}\left(120 \mathrm{~kg} \cdot \mathrm{s} / \mathrm{cm}^{2}\right)$ to the coil where it is heated up to a temperature of $+235{ }^{\circ} \mathrm{C}$. Therefore, the design, manufacture, and maintenance of HPH coils have their own specific features that define technical requirements for material, configuration, and weld joints [1-6].The appearance of one of the most widespread HPH coil is shown in Fig. 1.

The HPH coil consists of three tubeworks connected to each other with two butt welds. Tube sections made of carbon steel 20 and having 32 $\mathrm{mm}$ in diameter and a nominal wall thickness of $4.0 \mathrm{~mm}$ are used as blanks. One of the straight sections (the central section) used as blanks for tubeworks of HPH coils is as long as $7000 \mathrm{~mm}$, while the two other straight sections extends for 5980 and $5403 \mathrm{~mm}$, respectively. All mentioned sections have a vee 1-24-1 (C-24-1) formed during primary machining. So far, in Ukraine, all joints of HPH coils have been welded in fixed position by TIG manual welding, with welding cycle lasting, at least, 30-32 minutes per one weld joint,which not only restrains the welding efficiency, but also adversely affects the quality stability and requires pretreatment and involvement of highly skilled welders.

Unlike the TIG, the machine arc welding enables ensuring stably high quality and reliability of weld joints, insofar as in the case of machine welding the defect rate at the first handover does not exceed $5 \%$, whereas for the manual welding, it reaches $15-45 \%$. Also, the machine arc welding raises efficiency of weld works, at least, 5-6 times. Proceeding from the above and taking into consideration the pace of development of power engineering in Ukraine,it should be noted that the use of machine techniques for welding the joints of HPH coil tubeworks is the single option.

Since neither integrated equipment for machine welding of HPH coil tubeworks, nor corresponding processes have not been designed and are not available in Ukraine, the industrial corporations in various economic sectors have been forced to use foreign-made equipment and technologies for machine arc welding. However, they far from fully ensure the compliance with requirements of applicable regulations and standards in the field of power engineering of Ukraine, since some mandatory options are not available. In addition, they are expensive, insufficiently repairable, and require significant operation costs.

The Paton Electric Welding Institute and its specialized unit, the Research \& Engineering Center for Welding and Control in the Field of Power Engineering, have accumulated a certain experience in solving tasks related to the automation of large-scale weld works for the erection and repair of NPP units, as well as developed Ukrainian technologies for machine welding and manufacture and implementation of corresponding equipment. In 2008-2012, for the first time in Ukraine, they together have elaborated technological processes and created advanced competitive equipment for machine orbital GTAW of fixed joints of tubeworks having 7-76 $\mathrm{mm}$ in diameter and up to $3.0 \mathrm{~mm}$ wall thickness and 76-219 $\mathrm{mm}$ in diameter and up to $12.0 \mathrm{~mm}$ wall thickness [7], manufactured and tested trial samples of the equipment and prepared it to commercial production at Ukrainian corporations, introduced commercial samples of GTAW machines for welding tubeworks having 7-42 $\mathrm{mm}$ in diameter at separated structural units

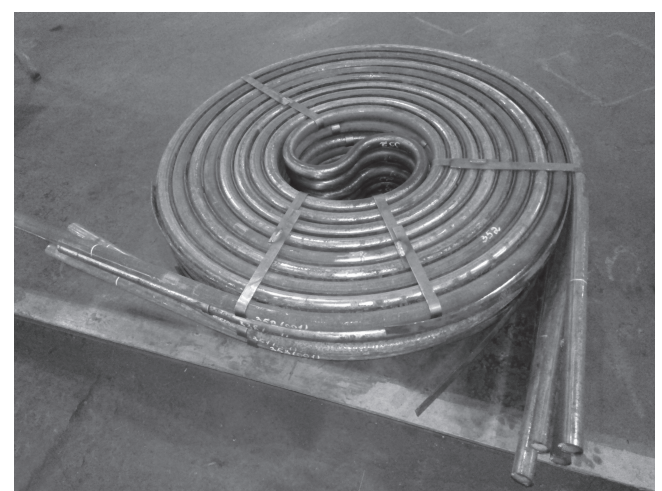

Fig. 1. General view of one of the most widespread versions of $\mathrm{HPH}$ coils 
of Energoatom NAEC [8, 9]. In 2015, for the first time in Ukraine they together have studied and elaborated technological processes and created advanced high-performance innovative equipment for preparing fixed butt joints to welding - facing tools TRC 38 UZ.1 for the steel tubes having a diameter of $14-38 \mathrm{~mm}$ and a wall thickness up to $5.0 \mathrm{~mm}$ and TRC $76 \mathrm{Y3} .1$ for the steel tubes having a diameter of $38-76 \mathrm{~mm}$ and a wall thickness up to $7.0 \mathrm{~mm}$, as well as tube-cutting machineTTC 660 UZ.1 for the steel tubes of infinite length with a diameter of $108-159 \mathrm{~mm}$ and a wall thickness of $15.0 \mathrm{~mm}[10,11]$.Trial samples of this equipment have been manufactured, tested, and prepared to commercial production at Ukrainian corporations. The equipment is expected to be put into operation in power engineering in 2018.

In 2017, in order to elaborate technologies for machine welding of HPH coil tubeworks and to create effective Ukrainian equipment for implementing these technologies, the Paton Electric Welding Institute and R\&EC WCPE have done the following research, survey, tests, and design works:

+ Engineering test studies to determine the effect of different techniques for machine arc welding on the efficiency of weld joints of HPH coil tubeworks and their quality that must comply with applicable regulations and standards for construction and safe operation of equipment and tubeworks of nuclear power plants, including PN AEG-7-009-89;

+ Identification and optimization of requirements for the equipment for machine welding of $\mathrm{HPH}$ coil tubeworks at NPP power units;

+ Development and justification of basic design solutions for the equipment for machine welding of HPH coil tubeworks;

+ Development and elaboration of design package and specifications for the front-end engineering design of the equipment for machine welding of HPH coil tubeworks and its main components.

Pursuant to PN AE and other applicable regulations and standards, weld joints of HPH coil tubeworksfor the straight sections of steel $20 \mathrm{tu}-$ bes having a nominal diameter of $32 \mathrm{~mm}$, a nominal wall thickness of $4.0 \mathrm{~mm}$, and a 1-24-1 (C-24-1) bevel shall have a limit reinforcement of $2.0 \pm 1.0 \mathrm{~mm}$ and a convexity of root weld of, at most, $1.5 \mathrm{~mm}$ or a concavity of, at most, $0.6 \mathrm{~mm}$. In this case, a shift of HPH coil tubework edges shall not exceed $0.4 \mathrm{~mm}$. The weld joints of these tubeworksare referred to the $3^{\text {rd }}$ grade (subgradeIIIc) according to PN AE G-7-010-89 and shall not have any flaws or defects except for those permissible by the mentioned PN AE and other applicable regulations and standards of Ukraine in the field of power engineering.

According to the applicable design documents for HPH coils, the weld joints of tubeworks shall be subject to $100 \%$ nondestructive test and destructive sampling for metallographic studies and mechanical tests. Visual instrumentation control and radiographic control are used as nondestructive methods. The destructive sampling of weld joints of HPH coil tubeworksis carried out in accordance with applicable manufacturing documentation and design documents, with chemical composition of weld metal checked, mechanical properties of welds measured, and metallographic studies performed.

Proceeding for the above, while carrying out the engineering teststudies both destructive and nondestructive methods, namely visual instrumentation control and radiographic control, metallographic studies, mechanical tests and determination of chemical composition of weld metal and heat affected area have been used. To this end, staff of the Chief Welder Department and Metal Quality Assurance Service of Atomenergomash Manufacturing Corporationof NAEC Energoatom have been involved with available certified standard means of control employed.

Simulators of HPH coil tubeworks made of steel 20 and having a nominal diameter of $32 \mathrm{~mm}$, a nominal wall thickness of $4.0 \mathrm{~mm}$, and edges machined in compliance with requirements of PNAEG-7-009-89,PNAEG-7-010-89 and OST 24.125.02-89 have been used as samples for the engineering test studies. 
The R\&EC WCPE has studied the feasibility of welding the joints of HPH coil tubeworks by using machine orbital GTAW and auto-extrusion or sequential penetration techniques developed at the RDD Institute for Field Engineering Technologies (Moscow) in 1970-1980 [12, 13]. Among the auto-extrusion technique advantages there a rather simple configuration of weld head (without filler rod feed) and the simplest requirement for edge pretreatment - 1-21-2 (C-39) bevel a common facing with a mandatory bevel of $0.3 \times$ $\times 45^{\circ}$ on the inside tube edge, which leads to difficulties with radiographic control. The first pass in the case of auto-extrusion is made with through penetration of tube wall (for the tubes with a wall thickness of nominal outer diameter ratio $S / D t u$ $b e>0.1$. After this, several additional passes without through penetration are done. The auto-extrusion technique is effective for welding the tubes withwall thickness up to $3.0 \mathrm{~mm}$, made of materials having a high linear expansion factor and a low heat conductivity, which is typical for corrosion-resistant austenitic steels (for example, 08X18H10T) [12, 13]. The sequential penetration technique is a type of auto-extrusion technique. Its advantage lies in the fact that the joints are welded at fixed parameters of welding conditions of each pass. The welding conditions are chosen based on partial penetration (up to $2 / 3$ wall thickness) at the first pass. With further passes the penetration depth gradually increases, and simultaneously weld reinforcement from inside and outside grows [12, 13]. The studies at RDDI FET and R\&EC WCPE have proved that the sequential penetration technique is advisable to be used for welding the tubes having a diameter up to $40.0 \mathrm{~mm}$ and a wall thickness less than $3.0 \mathrm{~mm}$.

The R\&EC WCPE engineering teststudies by numerous trial welds of HPH coil tubework simulators using GTAW equipment, including Ukrainian trial samples (ADC 625 UZ.1 machine for GTAW) [7, 9], have convincingly proved that it is impossible to obtain a stable quality of welds of HPH coil tubeworks using GTAW by auto-extru-

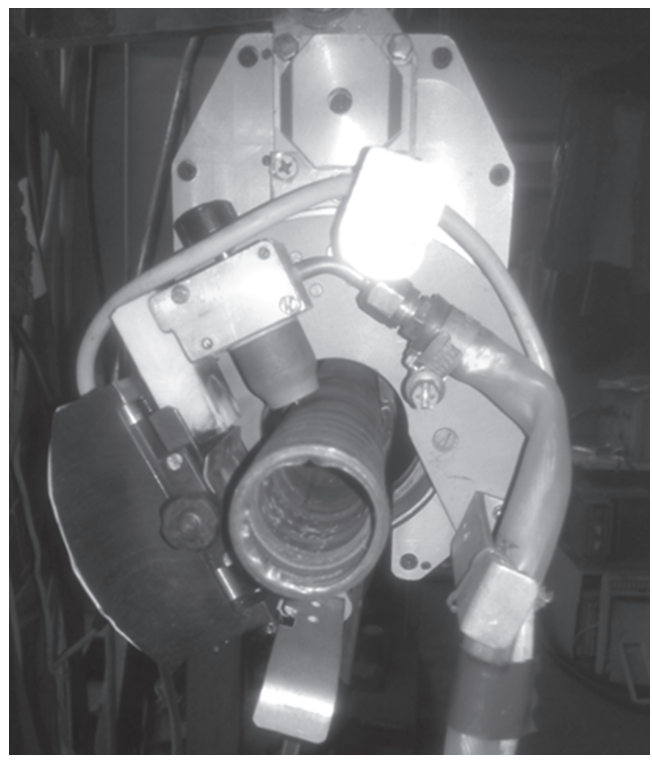

Fig. 2. Application of trial sample ADC 625 UZ.1 for GTAW of HPH coil tubework simulators

sion and sequential techniques because of electrophysical properties of HPH coil tubework material and dimensions.

Fig. 2 shows an example of application of ADC 625 UZ.1 machine trial sample for GTAW of HPH coil tubework simulators.

Firstly, as compared with the austenitic steels, the carbon steels (to which steel 20 belongs) have a much lower linear expansion coefficient and a significantly higher heat conductivity. This makes impossible to ensure sufficient compression loads for thermoplastic strains required for GTAW by auto-extrusion or sequential penetration techniques. Secondly, the nominal wall thickness of HPH coil tubeworks amounts to $4.0 \mathrm{~mm}$, while $S$ / Dtubeis 0.125 , i.e. close to the lower limit for the application of GTAW by auto-extrusion or sequential penetration techniques.

Upon the experiment results it has been established that in the case of GTAW, all these factors in combination with real conditions of heat removal enable to ensure neither through penetration of HPH coil tubework welds required by standards and design specifications, nor stable quality of weld formation. 
At the same time, long-term studies (including those carried out at the Paton EWI of the NAS of Ukraine) and practical experience have shown that the use of activating flux, for instance, oxide flux BC-2e developed at the Paton EWI, enables to essentially increase ( $2-3$ times) the penetration depth and to ensure a proper geometry of weld joints for TIG or GTAW [14-19]. The TIG or GTAW with the use of activating fluxes (hereinafter referred to as ATIG and GTAW-A, respectively) do not require beveling (only facing is necessary) for welding of $4-16 \mathrm{~mm}$ thick steel elements. Also, their advantages are a significant decrease in the number of required passes (as compared with TIG or GTAW) and, consequently, in the total welding time, a large reductionin consumption of welding materials and power, a low specific consumption of activating fluxes. These advantages have conditioned a successful application of ATIG and GTAW-A for manufacturing high-pressure vessels,for welding elements of landing wheels and engine bodies of aerospace vehicles, and so on [16]. Also, a successful experience has been accumulated in using ATIG and GTAW-A based technologies in trial welding of circumferential rotary and fixed joints of tubeworks in thermal and nuclear power engineering

Parameters of Rotator Simulator for Trial Welding ofRotary Joints of HPH Coil Tubeworks of NPP Units

\begin{tabular}{|l|c|}
\hline \multicolumn{1}{|c|}{ Parameter of rotator simulator } & Value \\
\hline $\begin{array}{l}\text { Nominal diameter of HPH coil tubeworks, } \\
\text { mm } \\
\text { Nominal wall thickness of HPH coil tube- } \\
\text { works, mm }\end{array}$ & 32 \\
$\begin{array}{l}\text { Welded item rotation speed range (welding } \\
\text { rate), rpm }\end{array}$ & $\geq 1,0-7,0$ \\
$\begin{array}{l}\text { Nominal voltage of single-phase power sup- } \\
\text { ply network, } 50 \text { Hz, } \mathrm{V}\end{array}$ & 220 \\
$\begin{array}{l}\text { Power source (AC-DC converter) of reverse } \\
\text { rotator electric drive, W } \\
\text { Nominal output voltage of DC of reverse ro- } \\
\text { tator electric drive, } \mathrm{V}\end{array}$ & $\geq 200$ \\
\hline
\end{tabular}

$[16,19]$. However, ATIG and GTAW-A have some disadvantages, in particular, the lack of tools for machine application of activating flux layer, complexity of control over its uniformity(which strongly depends on human factor), the lack of standard and certified measuring tools for this control, limitations on the time between the layer application and the start of welding and the use of aerosol activating fluxes. These disadvantages are the most likely reason for the fact that ATIG and GTAW-A have not been widely used in power engineering of Ukraine so far. The use of these techniques is not foreseen in the applicable regulations and standards and requires special approvals specified in PN AE.

Taking into consideration the disadvantages of ATIG and GTAW-A they cannot be deemed promising methods for welding HPH coil tubeworks.

One of the most widespread methods (at the piece production, preproduction, and commercial levels) is MAG welding. In the case of MAG technique, both electric welding arc and melt metal are protected from effect active carbon dioxide $\left(\mathrm{CO}_{2}\right)$ from air. This gas acts as oxidizer with respect to weld puddle metal and saturates it with carbon as a result of collision with gaseous mix formed from $\mathrm{CO}_{2}$ dissociation in the arc [20,21]. In the case of welding in $\mathrm{CO}_{2}$ environment with the use of rods of any diameter, two types of mass transport are possible:with periodical short circuits and without short circuits. For the MAG process, a high arc energy concentration and a better (as compared with manual arc welding) penetrability, which ensures a high efficiency of this welding technique.

At the same time, the MAG technique has several disadvantages, includinga high spatter at the most efficient welding conditions, which leads to additional labor inputs for cleaning the articles to be welded and the weld gun nozzle; a rather low quality of weld surface (unevenness and rough ripples); a low stability of arc welding with a large number of arc short circuits.

The engineering test studies have shown that in the case of welding the rotary joints of $\mathrm{HPH}$ 
coil tubeworks the MAG technique ensures a high efficiency of welding and a required penetration depth without any complications. However, proper weld formation gets slightly complicated. Hence, this technique is considered suitable for welding HPH coil tubeworks with certain reservations, provided the welding conditions are reproducible and their parameters are stable all welding cycle long.

At the same time, in all advanced economies and in Ukraine the machine welding in argon-based gaseous mixes (MIG+MAG) has got widespread [22-24]. In the case of MIG+MAG technique, thewelding process with fusible electrode takes place in environment consisting of argon ( $80-95 \%$ of the total volume) and a small amount oxygen of other oxidizing gas (usually, $\mathrm{CO}_{2}$ ), which notably improves the stability of arc burning andthe quality of weld formation and almost prevents welding conditions with arc short circuits.In this case, there are the range of welding conditions characterized with the drop metal transfer and the range with the jet (aerosol) transfer. As compared with MAG, this type of mass transfer has several technological advantages, among which the most important are satisfactory fusion coefficient and deposition rate factor (weight of electrode metal welded per ampere per hour and weight of metal deposited per ampere per hour, respectively), spattering and sputtering on base metal and weld gun nozzle, changes in weight of fused base metal and shape of weld penetration, as well as a much lower intensity of chemical effect on the weld puddle metal. Although, as compared with the MAG technique, in the case of MIG+MAG the penetrability decreases by $10-20 \%$ and to reach the same penetration depth it is necessary to increase weld current, the latter ensures the following:

+ A higher quality of weld joint (smooth surface with gradual transition to the base metal);

+ Several times reduction in electrode metal loss from spattering;

+ A notable reduction in labor input for cleaning the base metal from spatters;

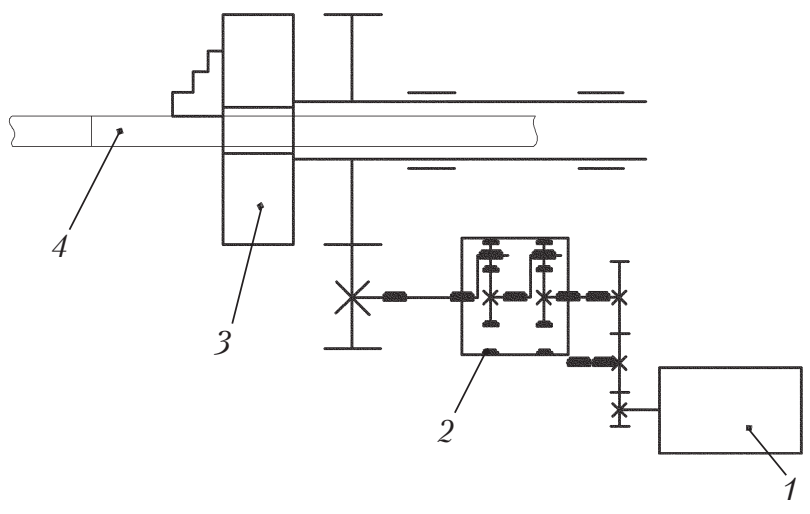

Fig. 3. Simplified kinematic model of horizontal rotator for engineering test works: 1 - DC electric motor with adjustable rotation speed, 2 - double-stage planetary reducing gear; 3 - spindle with movable clamps; 4 - tubework to be welded

+ Creation of favorable conditions for the use of impulse processes [23, 24];

+ An improvement in mechanical properties of weld metal;

+ Possibility of welding with extended stick-out of electrode wire.

Taking into consideration the advantages of $\mathrm{MIG}+\mathrm{MAG}$ technique as well as the results of engineering testworks at the Paton EWI and R\&EC WCPE, there are weighty reasons to state that for welding the rotary joints of $\mathrm{HPH}$ coil tubeworks of NPP units the MIG+MAG technique (mainly, in argon and $\mathrm{CO}_{2}$ environment)is one of the most effective and efficient methods.

To carry out the engineering testworks on welding the rotary joints of HPH coil tubeworks using the MAG and MIG+MAG techniques a model welding machine has been created. It consists of a control box BC-3005, a semiautomatic welder A-547 with trial samples of switch desk and welding gun designed for feeding the electrode wire with a nominal diameter of 1.0 and $1.2 \mathrm{~mm}$, and a rotator simulator (assembled, mounted, adjusted, and tested at R\&EC WCPE) with a DC $110 \mathrm{~W}, 24 \mathrm{~V}$ electric engine, type 13.120.45.1.2.1, an encoder 05.2420.1112.0100, $U_{p s}=5-24 V_{d c}$, a power source NES - 200-24, and a module of rotary actuator controller ИЦ616.20.11.000. A simpli- 
fied kinematic scheme of the rotator simulator is shown in Fig. 3, a principal electric circuit scheme is given in Fig. 4, and the simulator parameters are in Table 1.

The simulators of HPH coil tubeworks having a nominal diameter of $32 \mathrm{~mm}$, a nominal wall thickness of $4.0 \mathrm{~mm}$, a vee, and made of steel 20 prepared for welding in compliance with requirements for regulations, standards, and design specifications have been welded using the MAG and MIG+ MAG techniques. Before this, $2-3$ tack welds for each weld joint were made by the TIG technique in argon environment, at a weld current of 80$100 \mathrm{~A}$, using a trial sample of special power source ИЦ617 UZ.1 for TIG. Upon the results of several series of trial welding it has been established as follows:

+ The weld joints by the MAG technique with forced short circuits of thin electrode wire have

Basic Optimized Parameters of Equipment for MIG+MAG Welding of HPH Coil Tubeworks

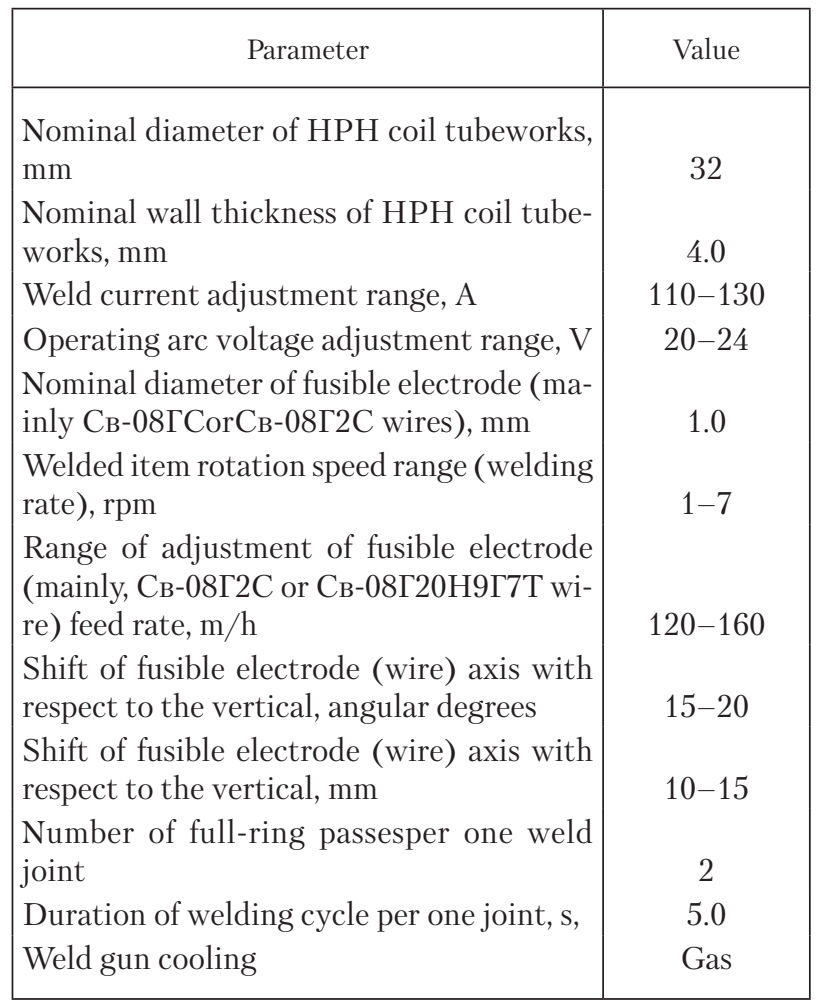

a necessary penetration depth, but require carefully selecting the welding conditions and keeping them with an accuracy of, at least, $\pm 5 \%$ while welding. Some simulators of HPH coil tubeworks have defects of welds, among which the most typical are sagging, undercuts, unsmooth transition to the base metal, and rough ripples of the facing surface;

+ The weld joints by the MIG+MAG technique not only have a required penetration depth, but also are almost free from inadmissible defects. This case is notable for a favorable transfer of electrode metalwith a negligible spatteringand contamination of welded article with electrode metal spatters, with the quality of welds fully meeting the requirements of PNAE Г-7-00989. This has been confirmed by tests using VIC and other methods for nondestructive and destructive control of weld joints of HPH coil tubeworks carried out at special independent certified laboratory of the Quality Assurance Department at Atomenergomash Manufacturing Corporation of NAEC Energoatom.

Upon results of experiment and engineering studies at R\&EC WCPE, the basic requirements for the $\mathrm{MIG}+\mathrm{MAG}$ equipment for welding of HPH coil tubeworks have been defined and optimized. These requirements underlie the Terms of Reference for R\&D project «Outline Design of Equipment for Machine Welding of HPH Tubeworks of NPP Units of Ukraine». The basic optimized parameters of equipment for the MIG+ MAG welding of $\mathrm{HPH}$ coil tubeworksare given in Table 2.

Also, it has been established that in addition to the requirements listed in Table 2, the equipment for machine welding of HPH coil tubeworks shall ensure, while welding, the stability of such parameters as weld current, operating arc voltage, rotation speed (welding rate), with an accuracy of, at least, $\pm 4 \%$, fusible electrode (wire) feed rate, with an accuracy of, at least, $\pm 5 \%$, duration of welding cycle, with an accuracy of, at least, $\pm 10 \%$, as well as reliable clamping and centering of both tubeworks to be welded to each other in order to 


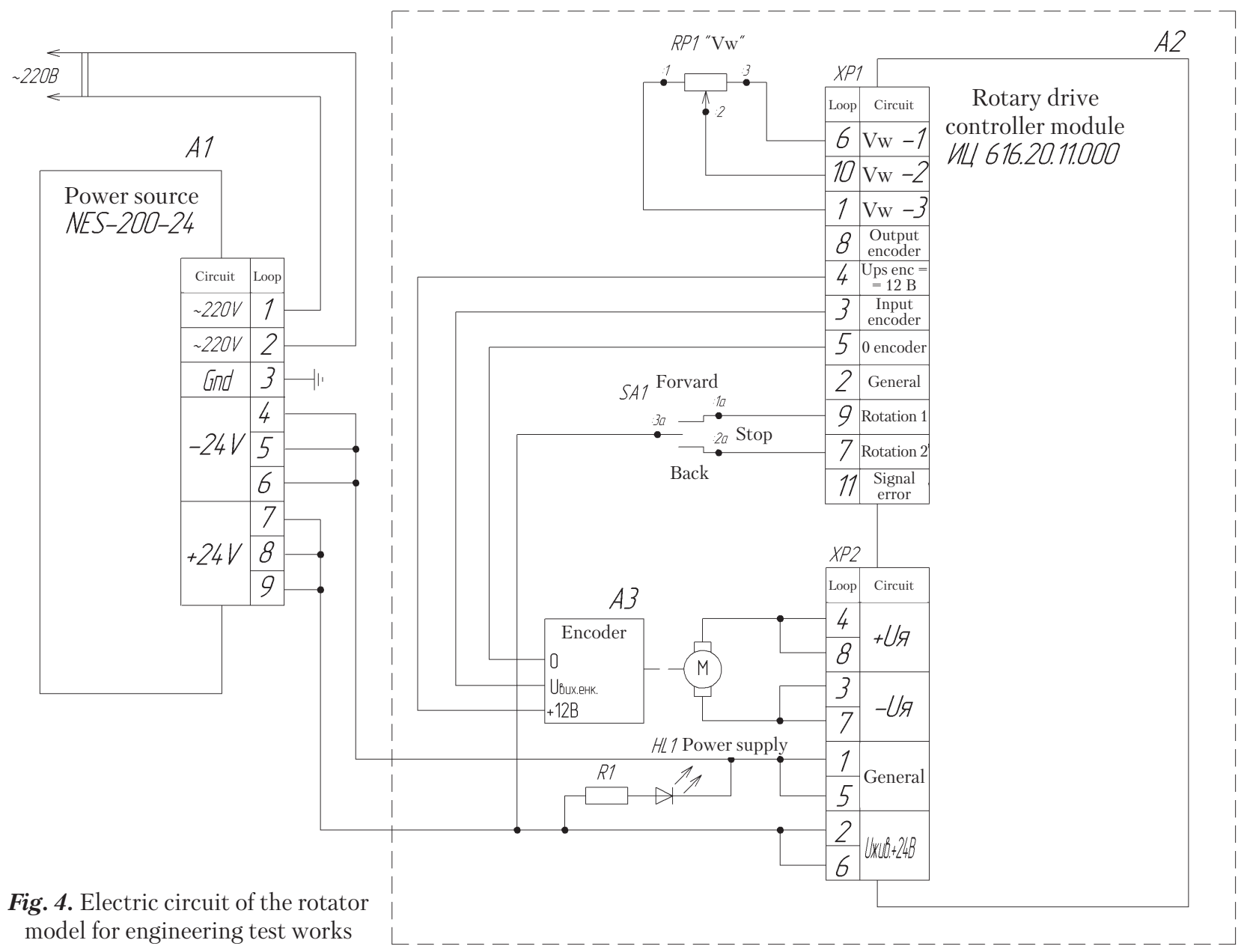

ensure their synchronous rotation and to avoid the use of preparatory tack welds.

Pursuant to the defined and optimized requirements of Terms of Reference for research and design project «Outline Design of Equipment for Machine Welding of HPH Tubeworks of NPP Units of Ukraine» a technical proposal on basic design solutions for equipment has been developed and approved. These solutions have underlain an outline design of equipment for machine welding of HPH coil tubeworks and its components developed at R\&EC WCPE.

One of the most important component of the equipment for machine welding of HPH coil tubeworks is its horizontal rotator that ensures a reliable fixation of tubeworks to be welded, their self-centering and almost synchronous rotation around the common longitudinal axis at the welding rate, all welding time long.

Fig. 5 shows a general view of horizontal rotator.

According to the outline design, the horizontal rotator for arc welding of tubeworks has two fixed supports - the driving 1 and the auxiliary 2 ones mounted on the common frame 3. Every support is equipped with a driving roller 4 and a bearingroller 5. On the driving support1, there is mounted a drive consisting of an electric engine 6 and a gear box 7 located on the same axis. The driving support 1 is equipped with a set of gear wheels. The first one ( 8 ) is mounted on the output shaft of gear box 7 and is coupled with idle gear wheel 9 that, in its turn, is coupled with gear wheel 10. 
The gear 10 is located on the same shaft with the driving roller 4 that sets the tubular billet 11 in motion with a welding rate. The set of gear wheels of the auxiliary support consists of coupled idle gear wheel 12 and gear wheel 13. The gear wheel 13 is located on the same shaft with the driving roller of the auxiliary support. This roller sets the second tubular billet 14 in motion with a welding rate. The idle gear wheels of both supports are connected to each other with shafts 15 and 16 viaexpansion coupling 17. The tubular billets are supported by the driving and the bearing rollers and are pressed to them by pressure rollers 18 and 19 mounted oncantilevers 20 and 21. The cantilevers change their spatial position using double cylinders 22, which gives required mating force between the driving rollers and the tubular billets. The tool (gun) 23 is fastened with clamp 24 fixed in corrector 25 that enables adjusting the gun positioning with respect to thebutt weld. The gun is set in the working position and put back to the position for billet load using the double cylinder 26 with embedded guide. The supports are placed at a distance from each other, which enables to weld the tubular billets and to avoid the temperature effect. The rotator is equipped with cradles 27 and 28 with ball joints for placement and shift of long tubular billets.

The rotator operates as follows: to load the tubular billets the gun 23 and the pressure rollers 18 and 19 are set in the starting position using the cylinder 26 and the cylinders 22 , respectively. The billets 11 and 14 are taken from the rack and put into the cradles 27 and 28, with their buttspositioned in the welding zone. After this, the left pressure roller 18 using the cylinder 22 presses the billet 11 to the driving roller 4 and the bearing roller 5 . The pressing force is adjusted by varying pressure of compressed air. The butt of billet 14 is interfaced with that of billet 11 and pressed by the roller 19 to the driving and bearing rollers of the auxiliary support 2 . In this way, the billets are centered with respect to each other.

The gun 23is led to the welding zone with further positioning with respect to the weld using the corrector 25 , by turning the clamp 24 with respect to the corrector and by moving the gun with respect to the clamp. The welding cycle is performed in accordance with preset welding conditions and algorithm. The billets are rotated due to friction with the driving rollers 4 driven by the electric engine6via the gear box 7 and toothed gear, with rotation frequency (and welding rate andstep-over moves) regulated by the electric drive. Rotating torque acts on both tubular billets, which prevents undesired displacement of edges. The kinematic errors caused by difference between the real dimensions of gear elements is compensated by flexible coupling 27. After the completion of welding cycle, the gun 23 and the pressure rollers 18 and 19 are put back to the starting position. For making the next weld joint the welded billets shift towards their longitudinal axis along the cradles 27 and 28 relying on the ball joints of the cradles until the required butt reaches a position for welding. Further, the next billets are loaded and the process is repeated.

A 200 W Lenze SPL62-6PVCR-056N21 DC geared motor designed for a nominal voltage of $24 \mathrm{~V}$ is used in the rotator. At the nominal voltage, it gives a torque moment of $50 \mathrm{~N} \times \mathrm{m}$, the number of revolutions of output shaft is $24 \mathrm{rpm}$, a reduction coefficient is 123.97. The geared motor is used in the rotator to ensure the real conditions for machine welding of joints of HPH coil tubeworks that shall revolve at a much lower speed as compared with the rotation speed of the output shaft.

The rotation speed of output shaft is stabilized using output information pulses of encoder 05.2420.1112.0100, $U_{\mathrm{ps}}=5-24 V_{d c}$ coaxially connected with free output of motor shaft. The geared motor rotation speed and direction are stabilized and controlled using a unified module of rotary drive controller ИЦ 616.20.11.000 and its external means of control (AC resistor « $V_{w} »$ and Forward - Stop - Back switch) designed at R\&EC WCPE. The NES-200-24 power source that is a AC-DC compact inverter with stabilization of DC output voltage ensures DC supply (including power supply circuits). While developing the out- 


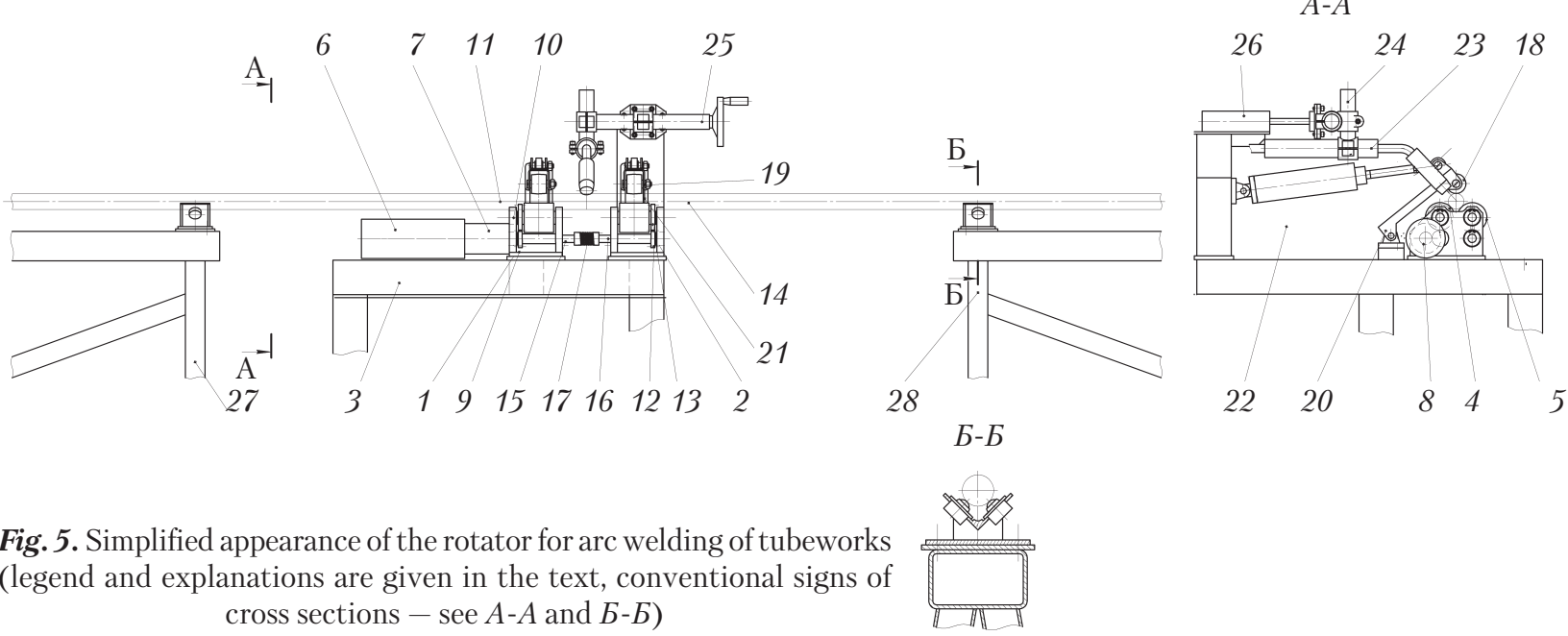

line design of horizontal rotator it was decided to place the module of rotary drive controller ИЦ 616.20.11.000 and power source of power supply circuits in the single housing configuration - rotator's drive control unit.

The output shaft of geared motor is reinforced with toothed gear $Z_{1}=17$ that rotates the idle gear wheel. Due to the toothed gear, the gear wheel $Z_{2}=51$ fixed on the shaft of driving rolling rotates simultaneously with revolution of this idle gear wheel. In addition, this idle gear wheel via its shaft is coaxially coupled with the shaft of other idle gear wheel that due to the toothed gear rotates the gear wheel fixed on the shaft of driving roller of the auxiliary support. The driving and bearing rollers, as well as the pressure roller controlled by a separate cylinder ensuremounting and clamping of the second straight section and its centering with respect to the first straight section. The shafts of idle gear wheels of the driving and auxiliary supports are connected to each other by a flexible coupling that enables almost synchronous rotation of both straight sections to be welded. This is one of innovative features of proposed horizontal rotatorfor arc welding of tubeworks [25].

The other specific feature of the proposed rotatory of equipment for machine welding of rotary joints of HPH coil tubeworks is the fact that welding of rotary joints does not require preliminary tack welds that can adversely affect the quality of weld joints.

Pursuant to the terms of reference, technical proposal, and outline design of the rotator, taking into consideration the necessity of shifting the axis of fusible electrode (the gun nozzle) with respect to the vertical the rotator has a two-position unit for gun feed. It ensures in the first (nonoperating) position such spatial location of the gun that in no way prevents fast and free mounting, clamping, and centering of tube straight sections to be welded to each other, while in the other (working) position, the gun location meets specified electrode stick-out, arc voltage (length) and shift of fusible electrode axis with respect to the vertical required for high-quality welding.To realize this, the two-position unit for gun feed includes a corrector of working position of the gun. The unit is controlled by means of pneumatic control with blocking operations that do not comply the given welding cycle. The two-position unit included in the rotator and algorithm of its operations also can be considered innovative solutions.

The configuration scheme of the rotator used for positioning the gun for a particular stage of welding cycle is shown in Fig. 6 . 


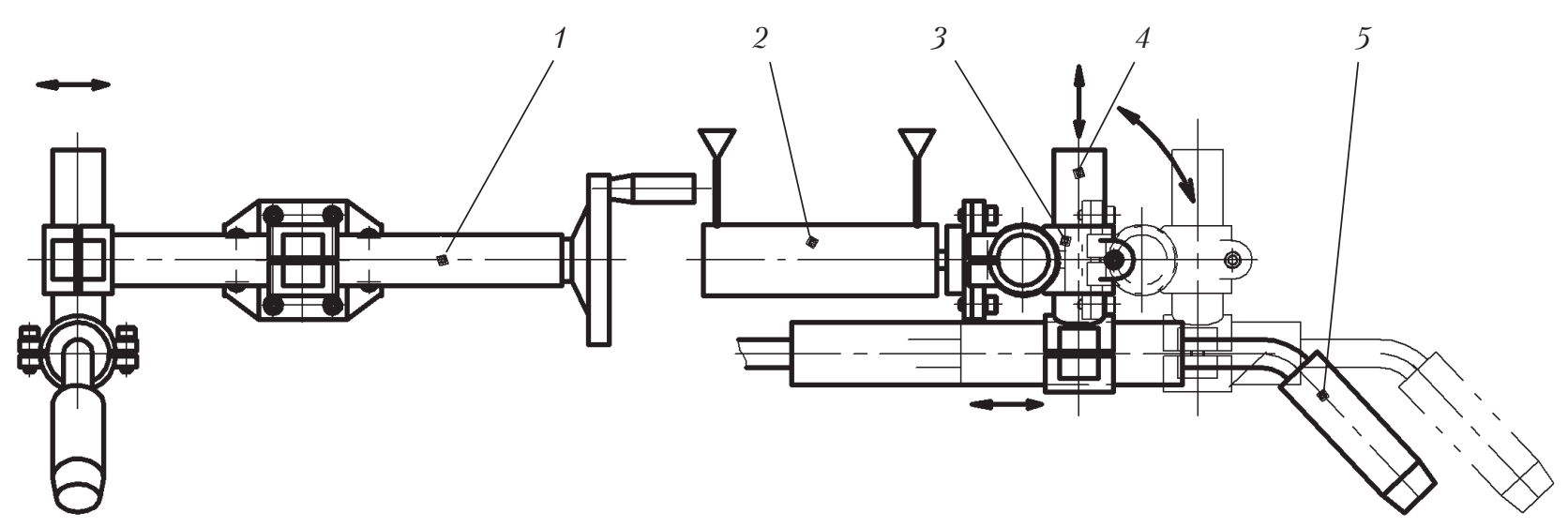

Fig. 6. Scheme of rotator for positioning the welding gun for certain stage of welding: 1 - transversal corrector; 2 - cylinder with guide; 3 - swivel clamp; 4 - support with clamp for gun; 5 - welding gun

The outline design of equipment for machine welding of HPH coil tubeworks foresees using a unit for compressed air preparation (CAPU) developed and manufactured by Camozzi for power supply to the pneumatic devices containing elements of pneumatic control. The CAPU reliably operates provided pressure of fed compressed air ranges from 0.40 to $0.63 \mathrm{MPa}$ (from 4.0 to 6.3 $\left.\mathrm{kg}^{*} \mathrm{~s} / \mathrm{cm}^{2}\right)$.

Upon the results of studies at the Paton EWI and R\&EC WCPE, TOR requirements, and technical proposal, the welding part of the equipment for machine welding of HPH coil tubeworks shall contain a welding cycle control unit (WCCU), an inverter-type welding power source with flator gently-sloping external volt-ampere characteristics (VAC), gas-cooled MIG/MAGgun and launch protection equipment unit (LPEU).

The WCCU shall control the welding process which cyclogramis shown in Fig. 7.

As RUN pulse leading front reaches WCCU, a gas valve is triggered in the welding power source (WPS) and shielding gas starts to flow through the gun nozzle hole. This is the start of preset and smoothly adjustable time interval $\tau_{1}$ GAS BEFORE WELDING (Pregas) that lasts till the WPS, electrode wire feed drive, and rotator drive simultaneously turn on, whichexcites the welding arc by touch. The welding starts and lasts for a preset and smoothly adjustable time interval $\tau_{2}$ :

$$
\tau_{2}=\operatorname{Tn} p_{1}+k \times \operatorname{Tnp}_{2}=\varpi \times\left(d_{1}+k \times d_{2}\right) / \mathrm{V}_{\mathrm{w}},
$$

where $\operatorname{Tn} p_{1}$ is duration of the first full-ring pass of welding arc; $k=(1.10-1.15)$ is coefficient that factors duration of over lapping; $\operatorname{Tnp}_{2}$ is duration ofthe second (facing) full-ring pass of welding arc; $d_{1}$ is nominal inner diameter of $\mathrm{HPH}$ coil tubeworks; $d_{2}$ is nominal outer diameter of $\mathrm{HPH}$ coil tubeworks. As STOP pulse leading front reaches WCCU, the electrode wire feed drive is shut down, with welding current dropping by $25-30 \%$, arc voltage decreasing by $1.5-2.0 \mathrm{~V}$. The arc «stretching» starts and lasts for $\tau_{3}$ until its natural extinction as a result of wire burnout. During $\tau_{3}$ the crater of weld puddle at the joint of $\mathrm{HPH}$ coil tubeworks is welded-up. At the end of $\tau_{3}$, the WPS and rotator drive are shut down, and a preset and smoothly adjustable time interval $\tau_{4}$ «GAS AFTER WELDING» (Postgas) starts. In this time interval, the welding zone is blown with shielding gas (or gaseous mix). At the end of $\tau_{4}$, the gas valve shuts down and the welding cycle ends.

As the cyclogram (Fig. 7) shows, the WCCU provides:

+ two ways of controlling the operation of components and mechanisms of the equipment for 
machine welding of HPH coil tubeworks - the manual and the machine ones in two operation modes of equipment - ADJUSTMENT and WELDING;

+ smooth adjustment and presetting of electrode wire feed rate, Pregas duration, welding time (until STOP pulse leading front reaches), Postgas duration, and automatic stabilization while adjusting or welding.

The WCCU is configured as printed circuit board (PCB) on which all its elements, except for the control bodies are mounted. The control bodies can be installed either on the WPS control panel or on the panel of rotator drive control unit of the equipment for machine welding of HPH coil tubeworks, or (if necessary) on the operator station. The WCCU has respective plugs and sockets for connecting WPS circuits with the gasvalve and the electrode wire feeder, as well as the circuits of operator station and rotator of the equipment for machine welding of HPH coil tubeworks.

As a result of the engineering test studies it has been established that to reach high-quality multipass weld points of HPH coil tubeworks using the MIG + MAG technique, the optimal welding conditions shall have the following parameters: welding current ranging within $110-130 \mathrm{~A}$; operating arc voltage within $21-23 \mathrm{~V}$;and welding rate within $1-6 \mathrm{rpm}$. The wire (mainly Св-08ГC or $\mathrm{CB}_{\mathrm{B}}-08 \Gamma 2 \mathrm{C}$ ) with a nominal diameter of $1.0 \mathrm{~mm}$ can be used as fusible electrode, its feed rate shall range within $120-160 \mathrm{~m} / \mathrm{h}$. It has been established that among numerous inverter-type WPS available in the Ukrainian market, the inverter-type power source MIG/MAG/TIG/MMA 303 by Tesla Weld, which contains a semi-automatic machine for arc welding MIG 303 with a standard electrode wire feeder and a gun for semi-machine gas-cooled arc welding $\mathrm{MB} 15 \mathrm{AK}$ by $A B I C O R$ $B I N Z E L$ is the most suitablefor meeting the requirements of TOR and technical proposal solutions.

The basic specifications of MIG/MAG/TIG/ MMA 303 power source are given in Table 3.

The analysis of basic specifications of MIG/ MAG/TIG/MMA 303 power source has shown

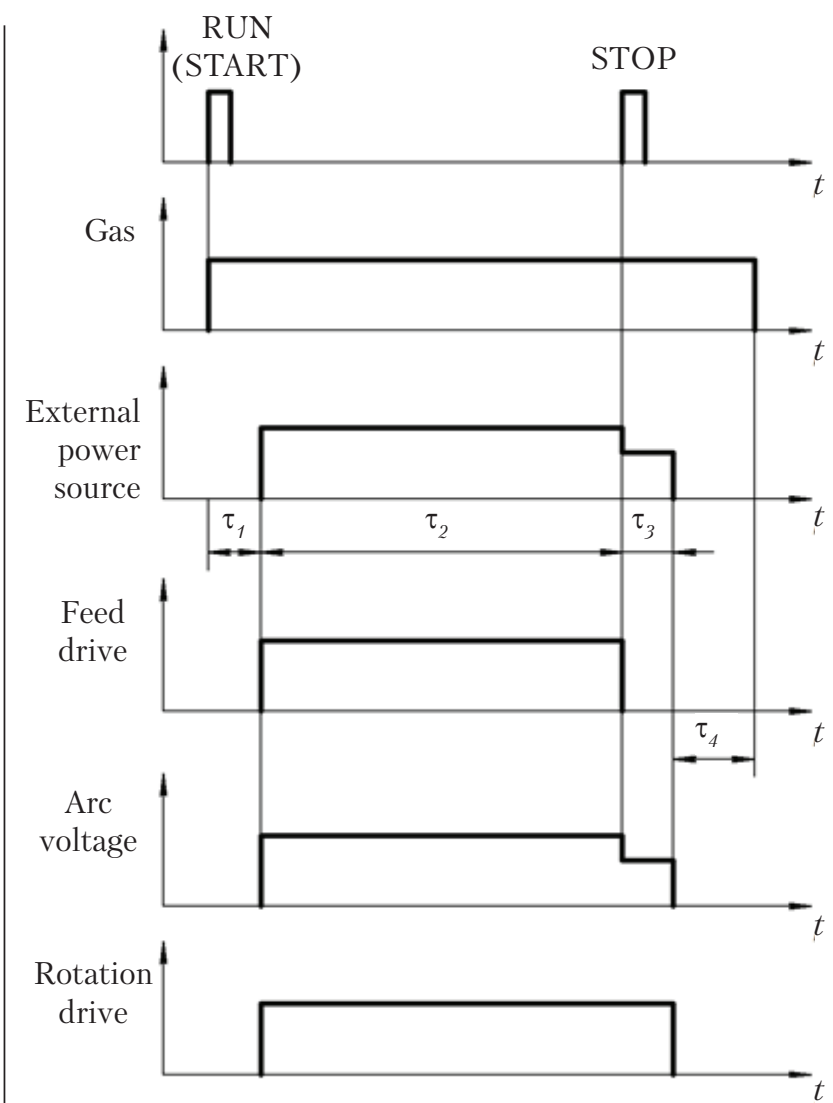

Fig. 7. Cyclogram of welding of HPH coil tubeworks: WPS welding power source; $\tau_{1}$ - Pregas time interval; $\tau_{2}-$ time of welding without interruption between the first and the second passes; $\tau_{3}$ - time interval of welding arc stretching before the arc extinction and welding-up of the crater; $\tau_{4}-$ Postgas time interval

that they, as well as VACof this WPS are suitable for meeting the technical requirements of TOR and engineering test works, except for duration of Pregas and Postgas intervals. In addition, pursuant to the operation algorithm of this power source as established by its developer, the natural burnout of electrode wire upon the completion of welding cycle with almost simultaneous automatic cut-off of welding current, stoppage of wire feed, and shutdown of gas valve. To remove the mentioned shortcomings of MIG/MAG/TIG/ MMA 303 power source (typical for other analogs available in the Ukrainian market, as well) R\&EC WCPE has developed a WCCU and elaborated a control system for this WPS, which 
caused the necessity to foresee the installation of a connector on its rear panel(wall) for interfacing the WCUU, provided the WCUU cannot be embedded into the WPS.

In the case of use of MIG/MAG/TIG/MMA 303 as WPS for presetting the welding conditions - arc voltage and electrode wire feed rate - standard means of control and LED indicators of this WPSlocated on its front panel (control panel)are used. The appearance of the panel is shown in Fig. 8.

Fig. 9 features the appearance of electrode wire feeder of MIG/MAG/TIG/MMA 303 power source.

The manufacture and tests of WCCU unit models and finalized control system of MIG/MAG/ TIG/MMA 303 power source have enabled establishing that this finalized power source that keeps its technical characteristics is capable of performing the welding cycle shown in Fig. 7. The adjustment range of Pregas duration is, at least, from 1.0 to $10.0 \mathrm{~s}$; that of Postgas duration is, at least, from 10.0 to $30.0 \mathrm{~s}$.

To simplify connecting the components of the equipment for machine welding of HPH coil tubeworks tothe power supply network, to enable

Table 3 of MIG/MAG/TIG/MMA 303 Power Source

\begin{tabular}{|l|c|}
\hline \multicolumn{1}{|c|}{ Parameter } & Value \\
\hline Welding current adjustment range, A & 32 \\
Duration of load under the highest welding & \\
current, \% & 80 \\
Operating arc voltage range, $\mathrm{V}$ & $14-28$ \\
Electrode wire diameter range, mm & $0.8-4.0$ \\
Rang of independent adjustment of electric & \\
wire feed rate, m/h & $60-600$ \\
Duration of Pregas (gas before welding), s & $0.8-1.0$ \\
Possible welding conditions for MIG + & \\
MAG technique & $2 \mathrm{~T}, 4 \mathrm{~T}$ \\
Duration of Postgas (gas after welding), s & $1.0-1.5$ \\
Single-phase network voltage, frequency 50 & \\
Hz, V & $200-240$ \\
Maximum electric power consumed, $\mathrm{kW}$ & 5.0 \\
Weight, kg & 15.5 \\
\hline
\end{tabular}

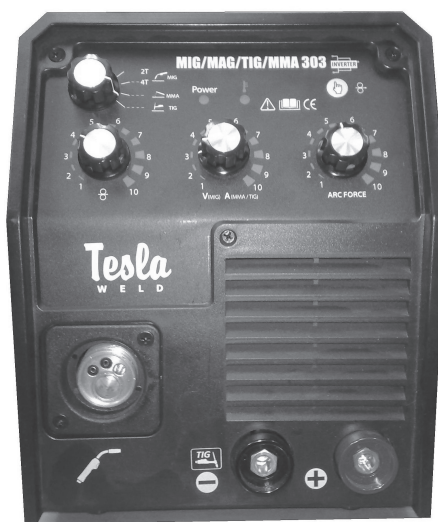

Puc. 8. Front panel (control panel) of inverter-type welding power source MIG/MAG/TIG/MMA 303

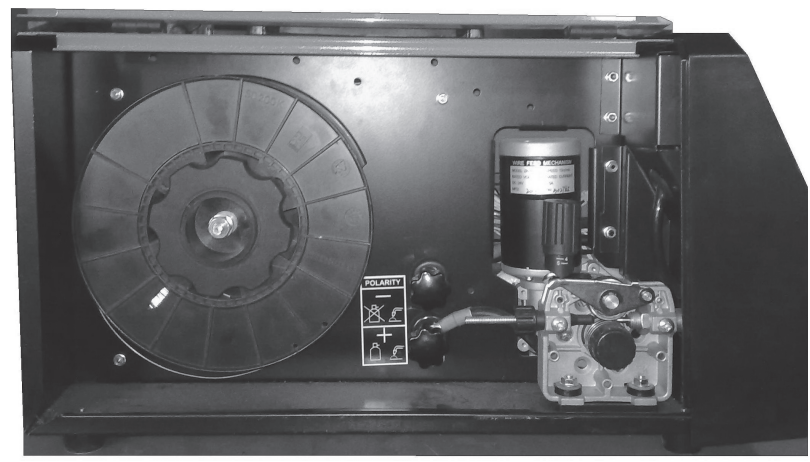

Puc.9. Electrode wire feeder of MIG/MAG/TIG/MMA 303 power source

the «Emergency Stop» mode with almost immediate and full deactivation of all its components and their additional automatic protection from long-term overload by feed current, and from permanent short circuit the R\&EC WCPE has designed and developed a LPEU.

The presence of automatic single-pole switchwith independent breaker inthe LPEUcircuit enables:

+ activation and deactivation of voltage supply to the equipment for manual welding of rotary joints of HPH coil tubeworks;

+ thermal protection of the equipment for manual welding of rotary joints of HPH coil tubeworksfrom long-term current overloads, i.e. from feed current exceeding more than 1.45 times its nominal value, and electromagnetic protection from short circuit currents (3-12 times excess 
of feed current) in the case of their appearance in the components of the equipment for machine welding of rotary joints of HPH coil tubeworks;

+ rapid (almost immediate, $t_{\text {resp }} \leq 2 \mathrm{~ms}$ ) remote deactivation of automatic switch, i.e. total shutdown of the equipment for manual welding of rotary joints of HPH coil tubeworksand all its components by operator command Emergency Stopor automaticallyin the case of current overloads or short circuit currents in the components ofthe equipment for machine welding of rotary joints of HPH coil tubeworks.

\section{CONCLUSIONS}

The engineering test studies at the Paton EWI and R\&EC WCPE have shown that for meeting the requirements of regulations and standards applicable in the field of power engineering of Ukraine, as well as the approved TOR concerning the quality and efficiency of welding of $\mathrm{HPH}$ coil tubeworks made of steel 20 and having a diameter of $32 \mathrm{~mm}$, a wall thickness of $4.0 \mathrm{~mm}$, and a bevel 1-24-1 (C-24-1), the most effective, costefficient, and suitable among machine arc welding methods used in Ukraine isthe multi-pass MIG + MAG technique (fusible electrode (wire with asolid diameter) in shielding gas environment (argon $-80-85 \%$, carbon dioxide - 1520\%). The MIG + MAG method enables:

+ high-quality weld for mation: smooth surface with a gradual transition to the base metal;

$+3-4$ times reduction in the electrode metal loss as a result of spattering, $8-10$ times reduction in labor input for cleaning the base metal from spatters, and improvement in mechanical properties of weld metal, as compared with the MAG technique;

+ the creation of favorable conditions for the use of pulse processes [23, 24];

+ welding with extended electrode stick-out [21]. The effectiveness of multi-pass MIG + MAG technique for welding HPH coil tubeworks has been established to significantly depend on the quality of their preparation for welding, which shall comply with requirements of regulations and standards applicable in the field of power engineering of Ukraine, including PNAE G-7-00889, PNAE G-7-009-89, andOST 24.125.02 - 89 concerning weld joints with 1-24-1 (C-24-1) bevel.

2. As a result of the engineering test studies it has been established that to assess the quality of weld joints of HPH coil tubeworks obtained by machine welding it is enough to use the nondestructive (VIC and RGC) and destructive sampling methods foreseen in the applicable design and technical documents and other regulations in the field of power engineering (including PNAE G-7-010-89). They ensure completeness, reliability, and accuracy of control required for verifying the compliance of weld joints of HPH coil tubeworks with PN AE G-7-009-89, PNAE G-7$010-89$, and OST 24.125.02 - 89, and other regulations applicable in power engineering of Ukraine as well as with national and international standards (for instance, European standards EN 12062, EN 25817, EN 13972). The quality assurance operations shall be based on the application of standard certified means of measurements commonly used in power engineering of Ukraine and other industries of Ukraine and approved by the State Committee on Technical Regulations and Consumer Policy of Ukraine.

3. As a result of the engineering test studiesand tests of simulators of individual units and mechanisms of the equipment for machine welding of $\mathrm{HPH}$ coil tubeworks, the basic requirements for this equipment and the basic parameters of welding conditions of MAG and MIG + MAG techniques for welding using electrode wire (mainly $\mathrm{CB}_{\mathrm{B}} 08$ ГC or $\mathrm{CB}_{\mathrm{B}}-08$ Г2C wire) with a nominal diameter of $1.0 \mathrm{~mm}$ have been identified and optimized. Two passes of arc welding have been established to be enough for obtaining high-quality welds of HPH coil tubeworks.

4. The electric drive that may contain a geared motor with a safe supply voltage (up to $27 \mathrm{~V}$ ), a double output shaft, an encoder that generates a fixed number of pulses per one full revolution engine shaft, and a control system (control of rota- 
tion speed i.e. welding rate) is important for the operation of units and mechanisms that ensure quick and smooth mounting, clamping, and selfcentering of HPH coil tubeworks (straight sections of tubes) before welding and their withdrawal after automatic end of welding cycle. Ithas been established that this geared motor shall have a capacity, of at least, $100 \mathrm{~W}$ and shall ensure the rotation speed of both straight sections ranging from1.0 to $7.0 \mathrm{rpm}$ using a speed reduction gear. In this case, the unified rotator drive module ИЦ 616.20.11.000 can be used as basis for the electric drive control system,

5. As a result of the engineering test studiesand tests of simulators of separate units and mechanisms of the equipment for machine welding of HPH coil tubeworksand the developed technical proposal, it has been established that for quick and smooth mounting, clamping, and self-centering of HPH coil tubeworks (straight sections of the tubes) a two-position weld gun feed unit is necessary. This unit shall enable, at least, in semiautomatic mode, such spatial location of the gun that in no way prevents fast and free mounting, clamping, and centering of tube straight sections to be welded to each other and their withdrawal after the full completion of the welding cycle, in the first (non-operating) position, and such gun location that meetsthe specified electrode stickout, arc voltage (length), and shift of fusible electrode axis with respect to the vertical required for high-quality welding, in the other (working) position. Tothisend, the two-position unit for gun feed shall have a corrector (or correctors) of the gun working position.

6. Having analyzed opportunities, configuration, reliability, engineering and economic indicators of the best Ukrainian and foreign samples available in the Ukrainian market, as well as the requirements of regulations and standards applicable in power engineering of Ukraine and TOR it has been established that none of the samples fully meets the requirements for the creation of Ukrainian equipment for machine welding of HPH coil tubeworks. In terms of engineering and economic indicators, the most cost-effective is an inverter-type welding power source MIG/MAG/ TIG/MMA 303 (developed and manufactured by Tesla Weld), which combines welding power source suitable for MIG + MAG welding with electrode wire of solid diameter, and semi-automatic machine MIG 303 for arc welding with a standard electrode wire feeder. However, even this power source needs upgrading its control system in order to ensure the operation of required components of welding cycle and the parameters of optimized welding conditions. Therefore, while developing a technical proposal and an outline design of the welding component of the equipment for machine welding of $\mathrm{HPH}$ coil tubeworks it was proposed and decided to upgrade the MIG/MAG/TIG/MMA 303 welding power source.

7. While developing the technical proposal for the equipment for machine welding of HPH coil tubeworksa scheme and configuration solutions for LPEU have been proposed. These solutions are based on developments of R\&EC WCPE and enable to fully meet the TOR requirements concerning safety and control system of the equipment.

8. The engineering test studies and tests of simulators of separate units and mechanisms of the equipment for machine welding of HPH coil tubeworksand the developed TOR, technical proposal, and outline design of this equipment and its basic components have ensured all preconditions for creating detailed specifications (including design and service documentation), manufacturing, and carrying out the trials and premarket testing of commercial samples of components of the Ukrainian equipment for machine welding of $\mathrm{HPH}$ coil tubeworks of NPP unitsand its commissioning.

The authors appreciate contribution of engineers I. Verteska and M. Drachenko to the studies and elaboration of technological processes; engineers $V$. Buriak, D. Oliyanenko, and A. Mukha to the creation and tests of simulatorsof individual units and mechanisms of the equipment for machine welding of HPH coil tubeworks and the development of 
outline design of this equipmentandits basic components; and engineers O. Kovaliuk, V. Prytyka, and $V$. Kurnishov to the elaboration of TOR and TP.

The research has been carried out within $R \& D$ project of the NAS of Ukraine in 2017 «The Elabo- ration of Technology for Machine Welding of $\mathrm{HPH}$ Coil Tubeworks of NPP Units with Fusible Electrode in the Shielding Gas Environment and the Creation of Trial Sample of Import-Substituting Equipment for Implementation of This Technology».

\section{REFERENCES}

1. Kameron, I. (1987). Jadernye reaktory. Moskva.320 s.

2. Shirokov, S.V. (1993). Fizika jadernih reaktoriv. Kyiv.288 s.

3. Buongiomo, J. (2010). PWR Description. Massauchsetts Institute of Technology.

4. Voronin, L.M. (1980). Osobennosti proektirovanija i sooruzhenija AJeS. Moskva. $192 \mathrm{~s}$.

5. NP - 045-03. Pravila ustrojstva i bezopasnoj jekspluatacii truboprovodov para i gorjachej vody dlja ob\#ektov ispol'zovanija atomnoj jenergii. Moskva. 2003. $49 \mathrm{~s}$.

6. Marushkin, V.M., Ivashhenko, S.S., Vakulenko B.F. (1985). Podogrevateli vysokogo davlenija turboustanovok TJeS $i$ AJeS. Moskva. $136 \mathrm{~s}$.

7. Makhlyn, N.M., Korotynskyi, A.E., Bohdanovskyi, V.A., Omelchenko, Y.A., Svyrydenko, A.A. (2011). Odno- i mnogo postovye sistemy dlja avtomaticheskoj svarki nepovorotnyh stykov truboprovodov atomnyh jelektrostancij. Avtomat. svar$k a, 11: 34-44$.

8. Bohdanovskyi, V.A., Havva, V.M., Makhlyn, N.M., Cherednyk, A.D., Tkachenko, A.V., Kudriashev, V.B., Kulykov, A.P., Kovaliuk, A.V. (2011). Primenenie avtomaticheskoj orbital'noj svarki pri izgotovlenii pogloshhajushhih vstavok kontejnerov hranenija otrabotannogo jadernogo topliva Avtomat. svarka, 12: 41-45.

9. Makhlyn, N.M., Popov, V.E., Fedorenko, N.S., Burba, A.V., Pyshnyi, V.M., Diukov, V.A., Hontarev, V.B. (2013). Primenenie avtomaticheskoj orbital'noj svarki pri izgotovlenii chehlov kanalov nejtronnyh izmeritel'nyh jadernyh reaktorov. Avtomat. svarka, 6: 29-34.

10. Lobanov, L.M., Mahlin, N.M., Smoljakov, V.K., Sviridenko, A.O. (2015).Obladnannjadljapidgotuvannjanepovorotn ihstikivtruboprovodiv do zvarjuvannja. Naukainnov., 11(5): 50-67.

11. Patent Ukraininakorisnu model' № 102582.Lobanov L.M.,Smoljakov V.K.,Vodolazs'kij V.C., Mahlin N.M. Portativn ijpristrijdljaobrobkitorciv ta krajoktrubpriihpidgotuvanni do zvarjuvannja.

12. Bukarov, V.A. (2002).Tehnologijadugovojavtomaticheskojsvarki v zashhitnyhgazah.Svarka v atomnojpromyshlennosti i jenergetike: Tr. NIKIMT. Moskva. 1: 149-210.

13. Ishhenko,Ju.S. Fiziko- tehnologicheskieosnovyformirovanijashvov v processedugovojsvarki.Svarka v atomnojpromyshlennosti i jenergetike: Tr. NIKIMT. Moskva. 2: 204-240.

14. Savickij, M.M., Kushnirenko, B.M., Olejnik, O.I. (1999). Osobennosti svarki stalej vol'framovym jelektrodom s aktivirujushhimi fljusami (ATIG-process). Avtomat. svarka, 12: 20-28.

15. Bajich, D.R., Savickij, M.M., Mel'nichuk, G.M., Lupan, A.F. (2002).Svarka ATIGkonstrukcionnyhstalej, primenjaemyh v jenergeticheskomoborudovanii. Avtomat. svarka, 9: 35-38.

16. Bajich, D.R., Mel'nichuk, G.M., Lupan, A.F., Savickij, M.M. (2002). Tehnika i rezhimyargono-dugovojsvarkistalej s aktivirujushhimifljusami. Avtomat. svarka, 10: 34-37.

17. Gordon, J.R. (1995). Perspectives on welding research end development it the USA. Weld. Reviero Intern., 9: 95-108.

18. Stankevich,I.Ja.,Dmitriev, V.I., Korida, V.L. i dr. (1982).PrimenenieaktivirujushhegofljusapriavtomaticheskojsvarketruboprovodovAJeS. Jenergeticheskoestroitel'stvo, 10: 19-20.

19. Potap'evskij, A.G. (1974).Svarka v zashhitnyhgazahplavjashhimsjajelektrodom. Moskva. $240 \mathrm{~s}$.

20. Kononenko,V.Ja. (2007).Svarka v sredezashhitnyhgazovplavjashhimsja i neplavjashhimsjajelektrodom. Kyiv. 266 s. 21. Svecinskij, V.G., Rimskij, S.T., Galinich,V.I. (1994).Svarkastalej v zashhitnyhgazovyhsmesjahnaosnoveargona vpromyshlennostiUkrainy.Avtomat. svarka, 4: 41-44.

22. Rimskij, S.T.,Svecinskij, V.G., Shejko, P.P., Pavshuk, V.M.,Zhernosekov, A.M. (1993).Impul'snodugovajasvarkanizk olegirovannyhstalejplavjashhimsjajelektrodom vsmesiargona s uglekislymgazom.Avtomat. svarka, 2: 38-41.

23. Aichele, G. (1990). Use of the pulsed technique - active gas metal - arc welding. Schweissenund Schneiden, 4: E62-E63.

24. Zajavka a 2017 11752vid 01.12.2017. Lobanov L.M.,Vodolazs'kij V.C.,Mahlin N.M., Korotins'kijO.€., Zhernosekov A.M., Popov V.C., Skopjuk M.I.Gorizontal'nijobertachdljadugovogozvarjuvannjadetalejtrubnihkonstrukcij.

Received 07.12.17 


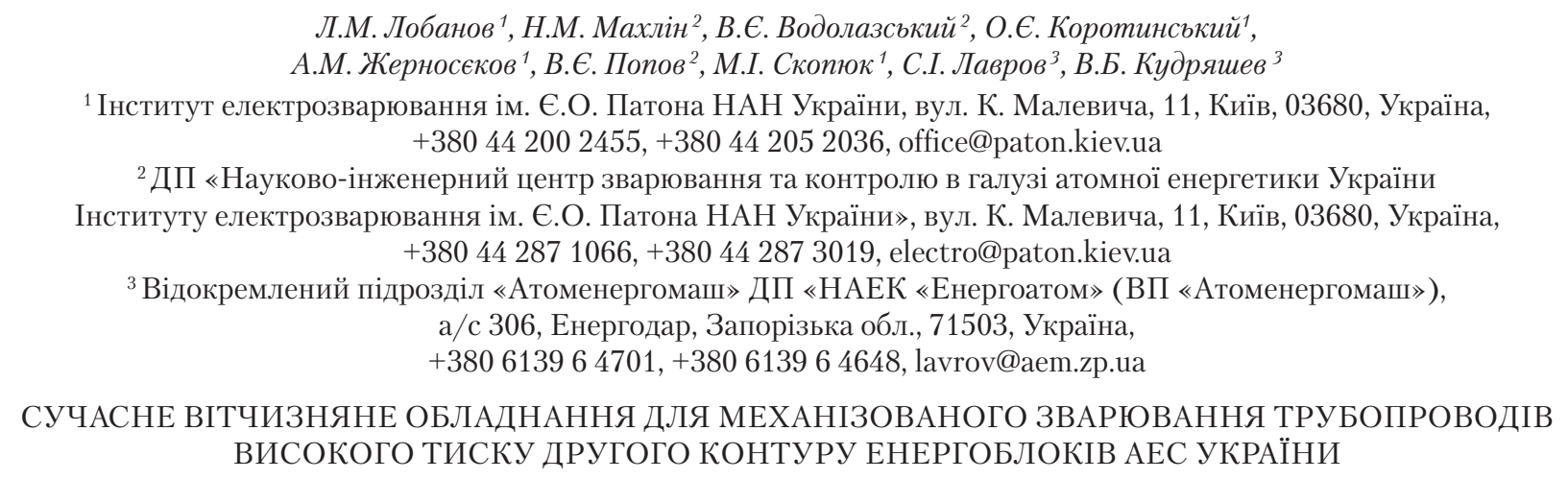

Л.М. Лобанов ${ }^{1}$, Н.М. Махлін ${ }^{2}$, В.С. Водолазськийㄹ, О.С. Коротинський', A.М. Жерносєков ${ }^{1}$, B.С. Попов ${ }^{2}$, M.I. Скопюк ${ }^{1}$, С.І. Лавров ${ }^{3}$, В.Б. Кудряшев ${ }^{3}$

${ }^{1}$ Інститут електрозварювання ім. Є.О. Патона НАН України, вул. К. Малевича, 11, Київ, 03680, Україна, +380 44200 2455, +380 44205 2036, office@paton.kiev.ua

2 ДП «Науково-інженерний центр зварювання та контролю в галузі атомної енергетики України

Інституту електрозварювання ім. Є.О. Патона НАН України», вул. К. Малевича, 11, Київ, 03680, Україна, +380 44287 1066, +380 442873019 , electro@paton.kiev.ua

${ }^{3}$ Відокремлений підрозділ «Атоменергомаш» ДП «НАЕК «Енергоатом» (ВП «Атоменергомаш»), а/с 306, Енергодар, Запорізька обл., 71503, Україна, +380613964701, +380613964648, lavrov@aem.zp.ua

\section{СУЧАСНЕ ВІТЧИЗНЯНЕ ОБЛАДНАННЯ ДЛЯ МЕХАНІЗОВАНОГО ЗВАРЮВАННЯ ТРУБОПРОВОДІВ ВИСОКОГО ТИСКУ ДРУГОГО КОНТУРУ ЕНЕРГОБЛОКІВ АЕС УКРӒ̈НИ}

Вступ. Принципово необхідними складовими другого контуру ядерних енергетичних реакторів 3 водою під тиском є підігрівачі високого тиску (ПВТ). Спіралі ПВТ призначено для підігрівання живильної води до необхідної температури з подальшою подачею їі на теплообмінник - парогенератор (ПГ). Пара, що утворюється у ПГ, надходить до турбіни, яка приводить у дію електрогенератори енергоблоку АЕС.

Проблематика. Основним чинником, що суттєво обмежує продуктивність створення зварних з'єднань трубних елементів спіралей ПВТ при їх виробництві й ремонті та викликає утворення в них дефектів, є спосіб їх зварювання, що до сьогодні застосовується у вітчизняній практиці - спосіб ручного зварювання неплавким електродом у середовищі інертних газів (далі - TIG) з подачею присадного дроту.

Мета. Дослідження способів підвищення продуктивності зварювання з’єднань трубних елементів спіралей ПВТ та рівня стабільності їх якості, а також розробка сучасного вітчизняного технологічного обладнання для впровадження відпрацьованих процесів.

Матеріали й методи. Для виконання досліджень було використано зразки - імітатори трубних елементів спіралей ПВТ зі сталі 20. Використано методи математичного та комп’ютерного моделювання, натурного макетування, дослідних зварювань, неруйнівного та руйнівного контролю, машинного проектування.

Результати. Досліджено можливість застосування різних способів дугового зварювання з'єднань трубних елементів спіралей ПВТ, визначено найоптимальніший з них, а також встановлено максимально ефективні параметри режимів зварювання та технічних вимог до вітчизняного комплексу технологічного обладнання для виконання цього процесу, розроблено технічне завдання (ТЗ) на виконання дослідно-конструкторських робіт з ескізного проектування такого комплексу та його основних складових частин, напрацьовано інноваційні технічні пропозиції (ТП) щодо їх складу, побудови, конструктивних та інших технічних рішень.

Висновки. Встановлено, що для виконання чинних вимог нормативних документів та погодженого і затвердженого ТЗ щодо якості й продуктивності виконання зварних з’єднань трубних елементів спіралей ПВТ зі сталі 20, найбільш ефективним та раціональним є спосіб багатопрохідного зварювання MIG + MAG - плавким електродом (електродним дротом суцільного перерізу) у середовищі суміші захисних газів. Розроблено та погоджено ТП щодо схемо-конструктивних рішень з побудови основних функціональних вузлів та механізмів обладнання для реалізації цього способу.

Ключов і слов 


\author{
Л.М. Лобанов ${ }^{1}$, Н.М. Махлин ${ }^{2}$, В.Є. Водолазскийㄹ, А.Е. Коротынский ${ }^{1}$ \\ А.М. Жерносеков ${ }^{1}$, В.Е. Попов ${ }^{2}$, М.И. Скопюк ${ }^{1}$, С.И. Лавров ${ }^{3}$, В.Б. Кудряшев ${ }^{3}$ \\ ${ }^{1}$ Институт электросварки им. Е.О. Патона НАН Украины, \\ ул. К. Малевича, 11, Киев, 03680, Украина, \\ +380 $442002455,+38044205$ 2036, office@paton.kiev.ua \\ ${ }^{2}$ ГП «Научно-инженерный центр сварки и контроля в отрасли атомной энергетики Украины \\ Института электросварки им. Е.О. Патона НАН Украины», \\ ул. К. Малевича, 11, Киев, 03680, Украина, \\ +380 44287 1066, +380 44287 3019, electro@paton.kiev.ua \\ ${ }^{3}$ Обособленное подразделение «Атомэнергомаш» ГП «НАЭК «Энергоатом» \\ (ОП «Атомэнергомаш»), а/я 306, Энергодар, Запорожская обл., 71503, Украина, \\ +380613964701, +380613964648, lavrov@aem.zp.ua

\section{СОВРЕМЕННОЕ ОТЕЧЕСТВЕННОЕ ОБОРУДОВАНИЕ ДЛЯ МЕХАНИЗИРОВАННОЙ СВАРКИ ТРУБОПРОВОДОВ ВЫСОКОГО ДАВЛЕНИЯ ВТОРОГО КОНТУРА ЭНЕРГОБЛОКОВ АЭС УКРАИНЫ}

Введение. Принципиально необходимыми составляющимими второго контура ядерных энергетических реакторов с водой под давлением являются подогреватели высокого давления (ПВД). Спирали ПВД предназначены для подогрева питательной воды до необходимой температуры с последующей подачей ее на теплообменник - парогенератор (ПГ). Образующийся в ПГ пар поступает в турбину, приводящую в действие электрогенераторы энергоблока АЭС.

Проблематика. Важным фактором, существенно ограничивающим производительность создания сварных соединений трубных элементов спиралей ПВД при их производстве и ремонте и вызывающих образование в них дефектов, является способ их сварки, доныне применяемый в отечественной практике - способ ручной сварки неплавящимся электродом в среде инертных газов (далее - TIG) с подачей присадочной проволоки.

Цель. Исследование способов повышения производительности сварки соединений трубных элементов спиралей ПВД и уровня стабильности их качества, а также разработки современного отечественного технологического оборудования для внедрения отработанных процессов.

Материалы и методы. Для выполнения исследований использовались образцы - имитаторы трубных элементов спиралей ПВД из стали 20. Использовались методы математического и компьютерного моделирования, натурного макетирования, опытных сварок, неразрушающего и разрушающего контроля, машинного проектирования.

Результаты. Исследована возможность применения разных способов дуговой сварки соединений трубных элементов спиралей ПВД, определен наиболее оптимальный из них, а также установлены максимально эффективные параметры режимов сварки и технических требований к отечественному комплексу технологического оборудования для выполнения этого процесса, разработано техническое задание (Т3) на выполнение опытно-конструкторских работ по эскизному проектированию такого комплекса и его основных составных частей, наработаны инновационные технические предложения (ТП) в отношении их состава, построения, конструктивных и других технических решений.

Выводы. Установлено, что для удовлетворения действующих требований нормативных документов, и согласованного и утвержденного ТЗ касательно качества и производительности выполнения сварных соединений трубных элементов спиралей ПВД со стали 20 наиболее эффективним и рациональным является способ многопроходной сварки MIG + MAG плавящимся электродом (электродной проволокой сплошного сечения) в среде смеси защитных газов (аргон $-80-85 \%$, углекислый газ - 15-20\%). Разработаны и согласованы ТП по схемно-конструктивным решениям построения функциональных узлов и механизмов оборудования для реализации этого способа.

Ключевые слова: ПВД, спирали ПВД, механизированная сварка, сварочный вращатель. 